ALICJA WITALISZ

Pedagogical University of Cracow

alicja.witalisz@up.krakow.pl

\title{
POLISH FACES OF ENGLISH ACRONYMS AND ALPHABETISMS: AN ILLUSTRATION OF CONTACT-INDUCED LINGUISTIC DIVERSITY (PART 2)
}

Keywords: acronym, alphabetism, abbreviation, adaptation, language contact, borrowing

\begin{abstract}
Didżej and didżejować appeared in Polish due to language contact and loanword assimilation processes; the former is the English noun $D J$ in graphic disguise, the latter is a Polish verbal derivative that conceals the English etymon. The article focuses on discussing and exemplifying the multiple ways in which English acronyms and alphabetisms are assimilated and integrated in the Polish lexical and grammatical systems. Part 1 of the article discusses loanword adaptation processes that have been identified for English lexical loans in several European languages. The linguistic outcomes of loanword adaptation processes, which both occur during the borrowing process and follow it, serve to support an observation that intensive lexical borrowing from English is a changeprovoking and development-motivating process that leads to linguistic diversity rather than linguistic homogeneity. An illustration of contact-induced linguistic diversity with corpus-driven data is preceded with a brief discussion of English abbreviations, which, in Part 2, are contrasted with their "polonized" versions that undergo formal, semantic and pragmatic changes in the recipient language.
\end{abstract}

\subsection{Introduction to part 2}

English-sourced acronyms and alphabetisms (A\&As), just as other foreign lexical loans, are likely to undergo various assimilation processes in the recipient language. The changes that occur both during the borrowing process and at the post-borrowing 
phase are triggered by the genetic remoteness and structural discrepancies between the languages in contact, and by the recipient language intrinsic features, such as for instance the high inflectionality level in Slavic languages. Following the types of contact-induced change identified in Part 1, Sections 4.1-4.9 address several types of loanword adaptation (nativization) processes that are illustrated with corpus-driven material. We will also address the issue of orthographic styling of A\&As and the suggested implementation of Polish spelling rules in the A\&As borrowed from English.

\subsection{Phonological adaptation of English A\&As in Polish}

Taking into account considerable differences between the phonological systems of the two languages in contact, it is not improper to say that all A\&As borrowed from English have been adapted phonologically in Polish. Their phonological adaptation is a varied and, in some cases, unpredictable process. Perhaps the most striking mode of phonological adaptation of English abbreviations in Polish is changing English alphabetisms into acronyms in Polish, i.e. pronouncing the original sequence of letters as a word in the recipient language. The pronunciation of the word is determined by its spelling and follows the Polish phonetic system; consider the following examples:

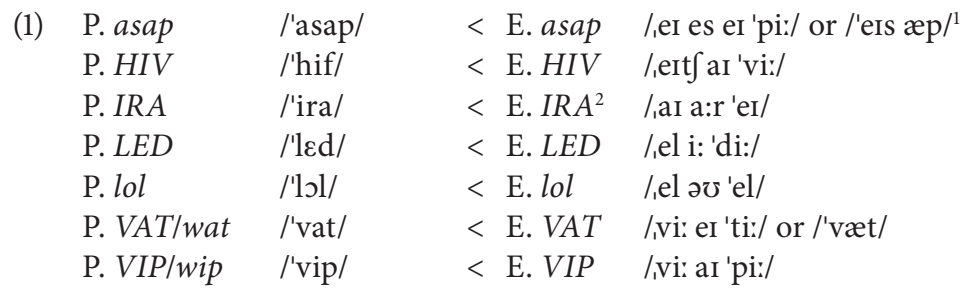

Yet, in the majority of English alphabetisms used in Polish, the phonological adaptation involves the substitution of the original, English phonetic value of each of the component letters with the phonetic value of the same letter in the Polish alphabet. This kind of phonological adaptation occurs when the combination of letters used in the English alphabetism cannot be read as a word in Polish, e.g.:

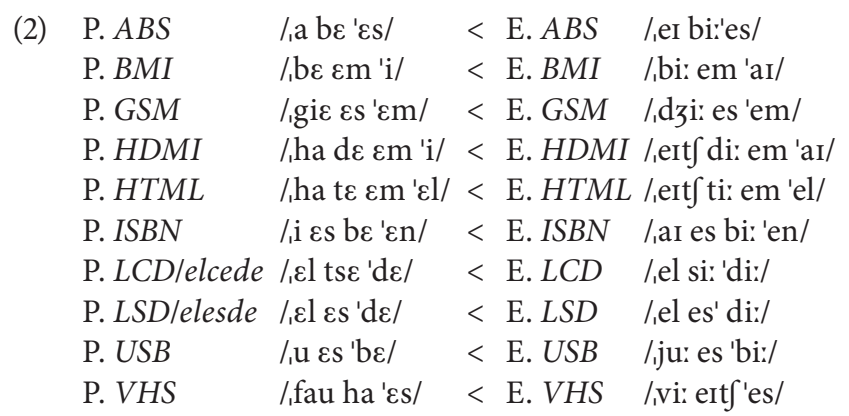

English pronunciation of A\&As after OLD and LPD.

2 Irish Republican Army. 

P. $W C / w c \quad /, \mathrm{vu}$ 'tse/
$<$ E. WC /,d $\Lambda$ blju: 'si:/
P. WTC /,vu t $\varepsilon$ 'ts $\varepsilon /$
$<$ E. WTC /,d $\Lambda$ blju: ti: 'si:/
P. $W W W \quad /, v u$ vu'vu/
$<$ E. $W W W / \mathrm{d} \Lambda$ blju: $\mathrm{d} \Lambda$ blju: 'd $\Lambda$ blju:/

In a few cases a close-to-the-original pronunciation of an English alphabetism is preserved in Polish, which means that for instance English GPS /dzi: pi: 'es/ is pronounced by Polish speakers as /dzi pi ' $\varepsilon s /$, and not as /gie pe ' $\varepsilon s /$, which would be a pronunciation based on the substitution of the phonetic value of the component letters as in the examples in (2). Instead, the English vowel sounds are replaced with their closest Polish equivalents. Other examples of this type of adaptation include, e.g.:

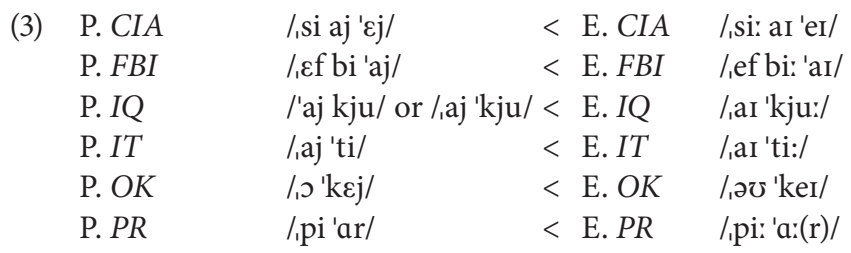

As for English acronyms used in Polish, their phonological adaptation involves spelling-based pronunciation that follows the phonetic system of Polish, as in:

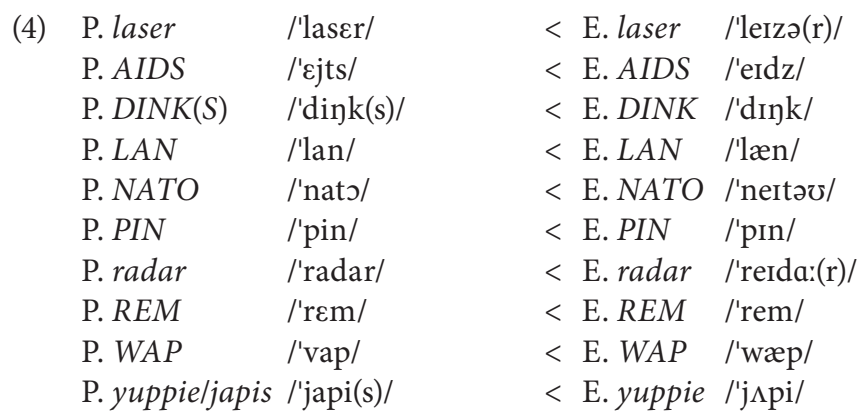

English abbreviations used in Polish electronic communication, such as e.g. idk (I don't know), nvm (never mind), are not examined for lack of data concerning their pronunciation by Polish users.

\subsection{Graphic adaptation of English A\&As in Polish}

A certain portion of English abbreviations used in Polish undergo graphic adaptation, which marks a high degree of loanword integration in the recipient language. With a few regular exceptions, such as for instance word-final devoicing of consonants or a handful of diagraphs (e.g. $c z=/ \mathrm{t} / /, d \dot{z}=/ \mathrm{d} z / /$ ), it may generally be stated that the pronunciation of Polish words reflects their spelling. This is the reason for the graphic adaptation of English abbreviations, and loanwords in general. The different ways of pronouncing the same letters in Polish and English, as in yuppie: the letter $y$ corresponds to the phoneme / $\mathrm{j} /$ in English and / $\mathrm{i} / \mathrm{in}$ Polish, while Polish /j/ is 
rendered with the letter $j$, and the non-existence of certain English letters in Polish, such as $v$ in VIP: ${ }^{3}$ the phoneme $/ \mathrm{v} /$ corresponds to the letter $w$ in Polish, result in the following:

\section{(5) P. japi < E. yuppie}

„... wydanie w ciągu nocy $1 / 3$ nauczycielskiej pensji. Jak się jest japi, to się może”

['... spending $1 / 3$ of a teacher's salary in one night. You can do it only if you're a yuppie'] (2004, NKJP)

P. wip < E. VIP

„... na Wielkiej Krokwi [...]. Swój udział zapowiedziały też masowo wipy” [‘... a number of VIPs have confirmed their participation in the Wielka Krokwia ski jumping World Cup'] (2003, NKJP)

Although lower-case spelling harmonizes with Polish orthographic rules for abbreviations which are not proper names (see 4.10), it seems that in this case and also in (6), it is rather a case of recognizing those loan-abbreviations as lexicalized words in Polish. In (6), the adapted, Polish spelling of English alphabetisms reflects the way they are pronounced in Polish having undergone phonological adaptation through the substitution of the phonetic value of the component letters or through the replacement of English sounds with their closest Polish equivalents (see 4.1):

(6) P. erpegie < E. RPG

„... można twierdzić, że w erpegie gracze nie występują przeciwko sobie” [ ‘ $\ldots$ it can be claimed that in RPG players do not proceed against one another'] (2001, NKJP)

P. esemes < E. SMS

„Tylko podczas oglądania wyłącz komórkę - bo jak dostaniesz esemes to ....” ['Make sure to switch your cell phone off - because if you get a text message [sms] ...'] (2005, NKJP)

P. piar < E. $P R$

„By prowadzić piar, należy wpierw zdefiniować kształt własnego wizerunku” ['To be able to proceed with a PR activity, you must first define your own image'] (2009, NKJP)

P. didzej < E. DJ

„Po ... feerii fajerwerków didżej zaprosił zgromadzonych do wspólnej zabawy” ['Following ... a fireworks show, the DJ invited everyone to join the party'] (2005, NKJP)

All the Polish spellings of English A\&As presented in (5) and (6) are alternative and co-exist in Polish with the original English spellings. The spelling variant chosen by a Polish user seems to depend on the formality level of a written text.

3 It is interesting to note that e.g. E. VAT is rather unlikely to be adapted graphically to ${ }^{*}$ wat in Polish, for the inevitable homonymy with wat 'a unit of power' ( $<$ E. watt $<$ James Watt). Yet, Polish derivatives from VAT are often spelled with the letter $w$, cf. watowski [adj.], owatować [v.] (PWN) (see 4.5). 


\subsection{Morphological adaptation proper of English A\&As in Polish}

Morphological assimilation of loanwords may in fact involve three separate processes, which will be exemplified in sections $4.3-4.5$.

Morphological adaptation proper, which happens rather infrequently in the case of English loanwords in Polish, occurs during the borrowing process and may involve gender assignment, suffix attachment, suffix replacement and suffix reduction (Witalisz 2016: 54ff), which may condition the loanword inflectionality in the recipient language. We shall refrain from addressing gender assignment in abbreviations borrowed from English since it is not directly relevant to the present discussion. ${ }^{4}$ It is sufficient to say that while gender assignment is easy and rule-governed in cases such as VIP or VAT, both are masculine due to the fact that there is a consonant in word-final position, in other cases gender is unstable, e.g. AIDS can be either masculine or neuter in Polish despite the consonant sound in the final position.

Abbreviations form a specific group of lexemes and the suffixal change as part of morphological adaptation proper that has been observed in the collected material is suffix attachment that results in the so-called double plural (Fisiak 1961; MańczakWohlfeld 1995: 59). An English abbreviation is borrowed in a plural form to function as a singular form in Polish. To receive a plural form in the recipient language, a Polish suffix marking the plural number is added, as in the following examples:

(7) P. DINKSY [pl.] < P. DINKS [sg.] < E. DINK

„... ale i u nas znajduje coraz więcej zwolenników ideologia dinksów. To angielski skrót od zwrotu "double income no kids»" [ $\ldots$ there are more and more fans of the DINK ideology. This is an English acronym of "double income no kids"'] (2002, NKJP)

P. dipisi [pl.] < P. dipis [sg.] $<$ E. $D P^{5}$ "Jaki jest koszt zrealizowania wniosku o przywrócenie obywatelstwa na przykład w konsulacie niemieckim? Ile taki dipis, który najczęściej jest emerytem ...” ['What is the cost of renewing one's citizenship in let's say German Consulate? How much will a DP, who is retired ...'] (no date, NKJP)

\subsection{Inflectionality of English A\&As in Polish}

It is interesting to note that the users of a highly inflectional language such as Polish meet hardly any difficulties in inflecting English abbreviations. The NKJP provides ample evidence of the inflected forms of A\&As borrowed from English and their various graphic variants. In the majority of cases, inflection is possible without prior morphological adaptation proper, which would be impossible for instance in the case of English verbs in Polish. Consider the following examples with the grammatical case and number marked in capitals in square brackets:

4 On gender assignment in abbreviations borrowed from English see Przybylska (2010, 2012).

5 Displaced Person. 
(8) P. DINKS [sg.] < E. DINK

„... ale i u nas znajduje coraz więcej zwolenników ideologia dinksów [GEN.pl.]”

['... there are more and more fans of the DINK ideology'] (2002, NKJP)

„Ostatnio w którąś sobotę na TVN24 po południu był program o dinksach [LOC.pl.]”

['On a Saturday there was a TV show about DINKs'] (2008, NKJP)

P. dipis [sg.] < E. DP

„Ale wracam do sprawy tych dipisów [GEN.pl.]. Jaki jest koszt zrealizowania wniosku o przywrócenie obywatelstwa?" ['Let me return to the DPs case. What is the cost of renewing one's citizenship?'] (no date, NKJP)

P. VAT < E. VAT

„... różnica w cenie powinna być równa w przybliżeniu cłu i Vatowi [DAT.sg.]”

['... the difference in price should roughly equal the customs duty and VAT'] (2002, NKJP)

P. $H I V<$ E. $H I V$

„Podobno wszystkie pielęgniarki w szpitalu są zarażone HIV-em [INST.sg.]” ['Reportedly all nurses in the hospital are infected with HIV'] (2005, NKJP)

The examples in (9) illustrate the inflectional paradigm for the singular forms of P. GPS / dzipies (< E. GPS) in its graphically unadapted and adapted forms: ${ }^{6}$

(9) P. GPS / dzipies [NOM.sg.] < E. GPS

„Poszukiwania z użyciem GPS-u [GEN.sg.] nie przyniosły jednak rezultatów” ['Search with the use of a GPS has not brought any results'] (2003, NKJP)

„Już zwykłe monitorowanie pojazdu za pomocą dżipiesa [GEN.sg.] pozwala na ...” ['Simple monitoring of a vehicle with the use of a GPS allows for ...'] (2005, NKJP)

„Od ślepego posłuszeństwa GPSowi [DAT.sg.] nakazującemu przedzieranie się przez krzaki ..." ['Starting with a blind obedience to a GPS that makes you hack through the bushes ...'] (2005, NKJP)

„Żeby ... dżipiesowi [DAT.sg.] jak źle pokaże szczeliny liny i drabiny” ['So that ... the GPS, if it wrongly shows the slits, ropes and ladders'] (2009, NKJP)

„Budowa satelitów Navstar obsługujących GPS [ACC.sg.]” ['The construction of Navstar satellites used by the GPS'] (2000, NKJP)

6 Cf. also the paradigm for the graphically adapted form of $D J$ in Polish:

\begin{tabular}{llll} 
English etymon & CASE & SINGULAR & PLURAL \\
\hline DJ & [NOM.] & didżej & didżeje \\
& [GEN.] & didżeja & didżejów \\
& [DAT.] & didżejowi & didżejom \\
& [ACC.] & didżeja & didżejów \\
& [INST.] & didżejem & didżejami \\
& [LOC.] & didżeju & didżejach \\
& [VOC. $]$ & didżeju & didżeje
\end{tabular}




\begin{abstract}
„Niestety nie udało mi się wygooglać żadnego rozporządzenia o obowiązkowym wyposażeniu turysty w dżipies [ACC.sg.]" ['Unfortunately, I've been unable to google any regulations about obligatory tourist equipment such as a GPS'] (2006, NKJP)

„Zachipowanie komputerów przez zintegrowanie z GPSem [INST.sg.] pozwoliłoby ...” ['Chipping computers through integrating them with a GPS would allow ...'] (2008, NKJP)

„... wspomagał kierowcę swoim niezawodnym dżipiesem [INST.pl.]” [‘... supported the driver with his reliable GPS'] (2008, NKJP)

„Mam tracka szlaku na GPSie [LOC.sg.]” ['I have a track in my GPS'] (2002, NKJP)

„... że już nie wspomnę o mapie cyfrowej w dżipiesie [LOC.sg.]” [‘... not to mention the digital map in a GPS'] (2004, NKJP)
\end{abstract}

\title{
4.5. Native derivatives from English A\&As
}

English A\&As used in Polish exhibit much morphological potential and are used as bases to coin verbal, nominal, adjectival and adverbial derivatives with the use of native affixes. This again is a sign of a high degree of integration and institutionalization of English A\&A loanwords in the recipient language.

Abbreviation-based native verbal derivatives are coined with the Polish suffix -ować and are illustrated in (10) with authentic examples from the corpus (the verbs in context appear in their inflected forms):

\section{(10) VERBAL DERIVATIVES:}

P. esemesować 'to send a text message' $<$ P. SMS/esemes $<$ E. SMS

P. wapować ${ }^{7}$ 'to use WAP' $<$ P. WAP $<$ E. WAP

„... możesz sobie dzwonić, esemesować, wapować ... ściągać tapetki, motywy, itp.”

[ $`$... you can call, send text messages $[\mathrm{sms}]$, use WAP, ... download wallpapers, motives, etc.'] (2006, NKJP)

P. ircować 'to communicate through the Internet; to use IRC' $<$ P. IRC $<$ E. IRC

„Można, m.in. ircować i korzystać z poczty e-mail” ['You can, among others, use IRC and electronic mail'] (2000, NKJP)

„Wiecie co - aż wstyd się przyznać, ale nigdy nie ircowałam” ['Do you know what it is a shame but I've never used IRC'] (2001, NKJP)

P. owatowaćlovatować 'to impose a VAT' $<$ P. VAT $<$ E. VAT

„... jeśli same książki, to pół biedy, jeśli CD/DVD, mają ... prawo oclić i ovatować”

['... if it is only books, that's ok, but if it is CDs/DVDs, they can impose a VAT'] (2006, NKJP)

„Z prostego powodu ... bo usługa audioteksowa już jest raz opodatkowana VAT-em, jest owatowana" ["For the simple reason ... that the audiotext service has already been taxed with VAT'] (2000, NKJP)

7 Cf. P. wapować/vapovać (MSSiMP) < E. to vape 'smoking an e-cigarette' (FD). 
P. ememesować/MMSować 'to send a picture via a mobile phone' $<$ P. ememes/ $M M S<$ E. MMS

„Dziewczyny ememesowały w wyjątkowym, własnym stylu” ['Girls sent pictures via mobiles phones in their own unique style'] (2013, mtv.pl)

P. didżejować/DJ-ować ‘to act as a DJ' < P. didżej/DJ < E. DJ

„Dlaczego wolisz występować na żywo z prawdziwymi instrumentami, niż didżejować z płyt?" ['Why do you prefer to play real instruments and perform live rather than use CDs like a DJ'] (2008, NKJP)

If we remember the high inflectionality of verbs in Polish, marking person, number, gender, tense, mood and voice, each of the verbal derivatives is a potential source of several dozen of inflected forms which would hardly be recognizable as having a stem of English origin.

In the case of nominal derivatives, there is a wider choice of native nominal suffixes, e.g. -ek, -owiec, -ka, -nik. Due to the seven-case declension in Polish and the two numbers, each of the nominal derivatives may appear in up to fourteen different inflected forms, cf. the following examples:

(11) NOMINAL DERIVATIVES:

P. cefatka [coll.] 'CV' < P. CV < E. CV

„Forma i treść cefałki [GEN.sg.] musi być dobrana do stanowiska, o które się ubiegamy" ['The form and content of a CV must match the position we are applying for'] (2010, NKJP)

P. pecet [coll.] 'PC' $<$ P. $P C<$ E. $P C$

„Notebooki były znacznie droższe niż zwykłe pecety [NOM.pl.]” ['Notebooks were far more expensive than regular PCs'] (2004, NKJP)

P. elcedek [coll.] 'LCD' < P. $L C D<$ E. $L C D$

"A teraz elcedeki [NOM.pl.] masowo wlazły na rynek” ['And now LCD TVs have flooded the market'] (2005, NKJP)

P. erpeg [coll.] 'RPG' $<$ P. $R P G<$ E. $R P G$

„... powergaming jest jak najbardziej na miejscu, w końcu to strategiczny erpeg [NOM.sg.]" ['... powergaming is very much in place, after all it is a strategic RPG'] (2004, NKJP)

P. hivowiec 'a person infected with the HIV virus' < P. HIV < E. HIV

„Zresztą za parę dni idę do szpitala na oddział dla hivowców [GEN.pl.]” ['I am going to hospital in a few days, to a ward for people infected with HIV’] (1993, NKJP)

P. empetrójka [coll.] 'MP 3 ' $<$ P. $M P_{3}<$ E. $M P_{3}$

„Nic nie zapowiada, by w najbliższej przyszłości empetrójka [NOM.sg.] miała odejść do lamusa" ['It is unlikely that $\mathrm{MP}_{3}$ should go out of date in the nearest future'] (2005, NKJP)

P. ircownik 'a person who uses the IRC' $<$ P. IRC $<$ E. IRC

„Ircownicy [NOM.pl.] na ogół próbują sprawdzać, kto zarejestrował się na danym kanale [...] Ale IRC daje możliwość zachowania incognito" ['IRC players usually 
try to check who has registered on a particular channel ... But you can also stay anonymous on IRC'] (1995, NKJP)

P. watowiec 'a company that pays the VAT' $<$ P. VAT $<$ E. VAT

„Zarejestrowali się pierwsi «watowcy» [NOM.pl.]” ['The first VAT payers have registered'] (2000, NKJP)

P. wucet [coll.] 'WC' $<$ P. $W C<$ E. $W C$

„... jadę po kinkiety do mojego nowego wucetu [GEN.sg.] i lustro i baterie” [‘... I am going to get sconces for my new WC, and a mirror and taps'] (2003, NKJP)

English A\&A-based adjectives are coined in Polish with native -owski and -owy. Adjectives in Polish are marked morpho-syntactically for gender, number and case, so the derivatives in (12) are just starting points for a whole array of non-Englishlooking complex lexemes.

(12) ADJECTIVAL DERIVATIVES:

P. piarowy/piarowski $<$ P. piar/PR $<$ E. $P R$

„Najtęższy łeb piarowski nie wymyśliłby lepszego scenariusza” ['The best PR head wouldn't have thought of a better scenario'] (2006, NKJP)

„... ma teraz nie lada piarowy kłopot” ['... has a huge PR problem now'] (2010, NKJP)

P. HTMLowy < P. HTML < E. HTML

„... uruchamianiu się wraz z otwieranymi plikami HTMLowymi” [‘... starting together with the opening of HTML files'] (2001, NKJP)

P. hivowy $<$ P. $H I V<$ E. HIV

„Hivowe love story wydarza się nie tylko w kinie" ['A HIV love story does not only happen in movies'] (2009, NKJP)

P. watowski $<$ P. VAT $<$ E. VAT

„Kupiliśmy komputer i rachunek watowski mamy wystawiony na nas” ['We have bought a computer and the VAT invoice has been issued in our name'] (2011, NKJP)

P. ircowy $<$ P. $I R C<$ E. IRC

„... niedoświadczonego podróżnika na ircowy kanał ... wprowadzić w zakłopotanie.”

['... an inexperienced traveller on a IRC channel ... cause embarrassment'] (2001, NKJP)

P. vipowski $<$ P. VIP $<$ E. VIP

"Z zewnątrz samolot vipowski od standardowego różni się ...” ['The ouside of a VIP plane differs from this of a standard plane ...'] (2001, NKJP)

P. GPSowy < P. GPS < E. GPS

P. smsowy $<$ P. $S M S<$ E. $S M S$

„... automatyczny GPSowy system lokalizacji sprzężony z lokalizacyjno-smsowym serwisem" [' $\ldots$ an automatic GPS localization system coupled with an SMS-localizing service'] (2007, NKJP)

P. natowski $<$ P. NATO < E. NATO

„Kiedy tydzień temu natowski pilot pomyłkowo zbombardował cywilny konwój Albańczyków" ['When a week ago a NATO pilot mistakenly bombarded a civil convoy of Albanians'] (1999, NKJP) 
P. laserowy $<$ P. laser $<$ E. laser

„Zanim zatopią laserowy skalpel w czyjejś tkance, będą mogli przećwiczyć cały zabieg w cyberprzestrzeni" ['Before they sink a laser scalpel in someone's tissue, they will be able to train going through the whole surgery in cyberspace'] (1997, NKJP)

All English A\&A-based adjectives in Polish may function as bases for adverbs coined with the native suffix $-o$, as in:

(13) ADVERBIAL DERIVATIVES:

P. piarowo/piarowsko $<$ P. piarowy/piarowski $<$ P. $P R /$ piar $<$ E. $P R$

"Jest przygotowany piarowo, potrafi powiedzieć ..." ['As for PR, he is prepared, he can say ...'] (2008, NKJP)

„Rząd jak zwykle nabiera piarowsko opinię publiczną" ['The government as usual uses PR to cheat the public opinion'] (2008, NKJP)

P. gpsowo/dżipiesowo < P. gpsowy/dżipiesowy < P. GPS/dżipies $<$ E. GPS

„Znaleziona bezgpsowo, bo nie spisałem jednej współrzędnej" ['Found without a GPS, as I did not take a note of one coordinate'] (2011, NKJP)

„Wracam do węgierskiej trasy dżipiesowo ustalonej na najkrótszą ...” ['I am returning to the Hungarian route that was recognized as the shortest by the GPS ...'] $(2012$, NKJP)

P. htmlowo $<$ P. htmlowy $<$ P. HTML $<$ E. HTML

„... pisać niegramatycznie i wysyłać Htmlowo na grupę oraz spamować” [ $\ldots$... write ungrammatically and send [sth] using HTML to the whole group, as well as spam [sth]'] (2005, NKJP)

P. vipowsko $<$ P. vipovski $<$ P. VIP $<$ E. VIP

„Do konkurencji vipowsko-dziennikarskiej już się zgłosili ...” ['They have already volunteered to take part in a VIP-journalist competition ...'] (2007, NKJP)

P. laserowo $<$ P. laserowy $<$ P. laser $<$ E. laser

„Być może zostaną odtworzone laserowo obydwie wieże” ['Perhaps both towers will be laser reconstructed'] (2002, NKJP)

P. radarowo $<$ P. radarowy $<$ P. radar $<$ E. radar

„... myśliwce mające odpowiednie wyposażenie oraz sterowaną radarowo artylerię" ['... fighters have adequate equipment and artillery that is radar steered.'] (1999, NKJP)

\subsection{Pragmatic changes in A\&As borrowed from English}

The pragmatic function of a foreign word may change in the recipient language through the acquisition or loss of specific connotations (Pulcini 2002: 162; Dunn 2008: 60). We find cases of both amelioration and pejoration of meaning in English A\&A-based derivatives which are augmentative and diminutive forms that evoke negative and positive connotations, respectively. Consider the following examples: 
(14) P. japiszon [augmentative] 'yuppie' < P. yuppie/japi < E. yuppie „Polski japiszon ... był ubogim krewnym i ... karykaturą zachodnich dandysów” ['A Polish yuppie [derog.] ... was a poor relative and ... a caricature of western dandies'] (2001, NKJP)

P. hivol/hivolec [augmentative] 'a person infected with the HIV virus' $<$ P. $H I V<$ E. $H I V$ "Czego mądrego spodziewać się po HIV-olach" ['What wise can you expect from HIV-carriers [derog.]'] (2012, NKJP)

P. hivolec [augmentative] 'the HIV virus' $<$ P. HIV < E. HIV

„... gdyby nie uparcie biskupów w kwestii kondomów ... jakimś hivolcem” [‘... but for the bishops' stubbornness about condoms ... with some HIV [derog.]'] (2008, NKJP)

P. esemesik [diminutive] lit. 'a small text massage' $<$ P. esemes $<$ P. $S M S<$ E. $S M S$ „Wystarczy mały esemesik ... Będę wdzięczny” ['A text message [diminut.] will do ... I'll be grateful'] (2006, NKJP)

\subsection{Semantic adaptation of English A\&As in Polish}

Although the main motive behind borrowing foreign lexemes is naming foreign concepts, loanwords happen to undergo semantic change in the recipient language. Semantic deviation from the etymon is illustrated with two English alphabetisms that originally named in English only types of service. Polish speakers use the abbreviations sms and $m m s$ to refer to messages sent with the use of SMS (Short Message Service) and MMS (Multimedia Messaging Service), as in the following (some of the abbreviations in context appear in their inflected forms):

(15) P. SMS/sms/esemes 'a text message' < E. SMS

"Może to robić poprzez zestawienie połączenia głosowego lub przesyłając SMS” ['It can be done through making a phone call or sending a text message [sms]'] (2004, NKJP)

„Później prosił o wysłanie smsa do jego kolegi” ['Later he asked to send a text message [sms] to his friend'] (2006, NKJP)

\section{P. MMS/mms/ememes 'a picture/MMS message' < E. MMS}

„Dostawałam mms ale nie musiałam go ściągać z wapu” ['I got a picture/MMS message but did not have to download it from WAP'] (2006, NKJP)

„Właśnie wysłałam pierwszego w życiu mmsa z nowej-starej komórki” ['I’ve just sent my first picture/MMS message from my new-old cell phone'] (2008, NKJP)

„Kolega z pracy wysłał jej mmsem swoje nagie zdjęcia” ['A colleague from work has sent her his naked photos using a picture/MMS message'] (2008, NKJP) 


\subsection{Abbreviations loan translated from English}

Though the majority of English A\&As are borrowed as loanwords into Polish, there are also instances of covert loans. The full version of an English abbreviation is calqued and the resulting expression is abbreviated in Polish. Consider the following names of organizations, economic and scientific terms (Witalisz 2015: 168), as well as initialisms used in electronic communication, e.g.

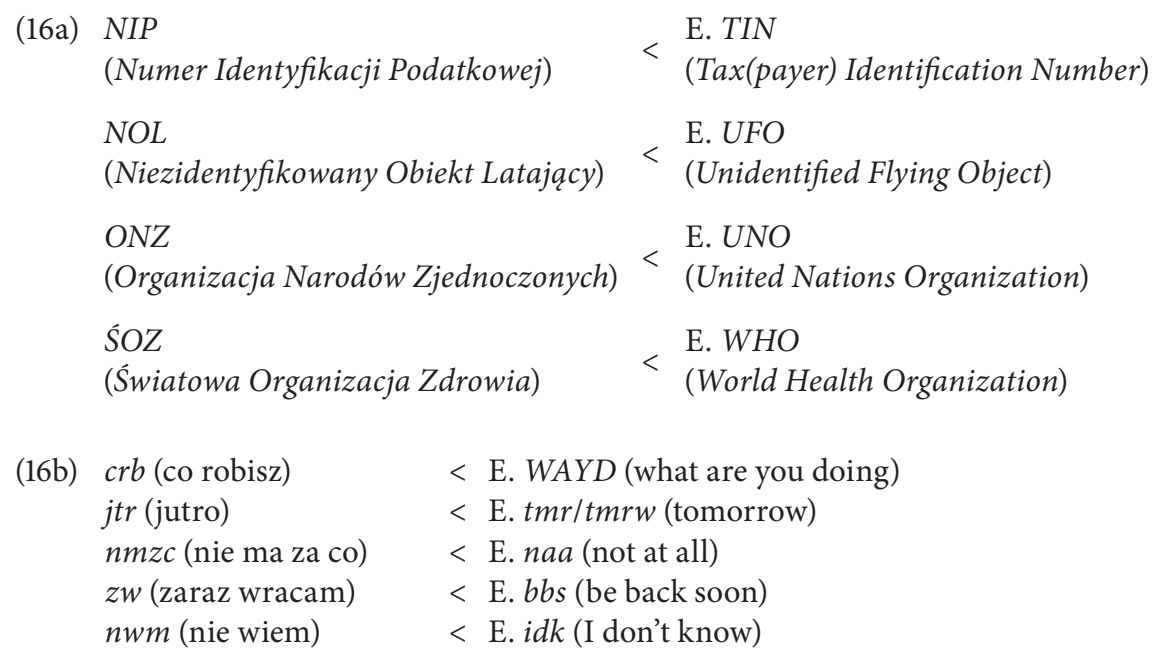

The last set of examples is evidence to the contact-induced boosting of some wordformation processes in Polish (see Section 6).

\subsection{English A\&A-based hybrids and blends in Polish}

English abbreviations happen to be attached to Polish lexemes to form hybrid creations that have no discoverable models in English, as in:

(17) P. HIVochron 'something that protects against HIV' (HIV + ochrona 'protection') „Nieskutecznego filtrowania przez HIVochron" ['Inefficient filtering through HIV-protector'] (2002, NKJP)

Some other hybrid expressions are in fact half-translated loanblends from English, as in:

(18) $\quad$ P. VIP rozmowa $<$ E. VIP call

„W pakiecie VIP rozmowy ze wszystkimi sieciami są nieograniczone” ['The package offers unlimited VIP-calls to all networks'] (2016, NKJP)

An English abbreviation may also be used creatively as a component of a newlycoined blend in the recipient language, as in:

(19) P. hivozorium 'a potential hospital for the infected with the HIV virus' (HIV+ (lepr)ozorium) 
„Chorzy na AIDS nie byli izolowani w hivozoriach (tak, jak są w leprozoriach izolowani chorzy na trąd)" ['Patients infected with AIDS were not isolated in HIV-osariums (as patients infected with leprosy are isolated in leprosariums)'] (2004, NKJP)

\subsection{Orthographic styling}

Finally, the issue of the orthographic styling of A\&As needs to be addressed. The corpus search has confirmed on many occasions that the spelling of English A\&As in Polish is often a matter of individual preference.

Since English abbreviations are not uncommon in Polish and their high frequency of use and usability foretell their institutionalization in this Slavic language, the implementation of Polish orthographic rules in the spelling of English A\&As has been proposed. Following the strict Polish rules that govern the orthographic styling of Polish A\&As, it has been suggested that proper name abbreviations borrowed from English, such as USA and UNESCO, should be still capitalized, which would comply with the English rule. For all non-proper name abbreviations, however, we should use lower case, e.g. vip, vat, ufo, pit, and aids would be the correct Polish spellings of English VIP, VAT, UFO, PIT and AIDS, respectively. Moreover, graphic adaptation should be implemented wherever possible, and for instance English $A B S$, $D J$ and GPS should follow the Polish orthographic system to become abees, didzej and $d \dot{z}$ ipies, respectively (Przybylska 2008: 110). It is clear that implementing these orthographic rules would result in further deviation from the foreign etymons and contribute to a greater linguistic diversity.

\section{Contact-induced intensification of native acronymization}

Some scholars monitoring the English influence on Polish in the last decades have observed an intensified productivity of some word-formation processes in Polish, which they consider a by-product of linguistic borrowing from English (cf. e.g. Waszakowa 2001: 99; Konieczna 2012: 70; Jaworski 2014: 35; Witalisz 2016: 148, Witalisz 2018).

Acronymization as a word-formation process has been used in the Polish technical and medical jargons over the last century, but it has become increasingly productive, also in general Polish, in the last thirty years (WSSiS 2007: 5-6), which coincides with intensive lexical borrowing from English. Polish journalists, advertisers and young people resort to formerly unproductive word-formation processes, such as acronymization, blending, clipping and compounding, to model their language use on the American patterns of presenting news, creating commercials, and on the slang language of various American subcultures. English abbreviations, borrowed initially in the form of lexical loans, happen to be replaced, especially in young Poles' online communication, by their loan translated versions (see the examples in 16b) and, later, by independent native "e-cronyms" ("e-kronimy", SSiSA), 
that exploit native language material and are modelled on English abbreviated expressions, e.g.:

(20) P. bd (będę 'I'm planning to be')

P. $c b$ (Ciebie 'You' [GEN.])

P. jj (już jestem 'I’m back')

P. $k c$ (kocham cię 'I love you')

P. $k \operatorname{tr}$ (które 'who, which')

P. 3maj się (trzymaj się 'Keep well')

P. $m g$ (mogę 'I can')

P. $n k$ (niech ktoś (np. podrzuci mi jego numer) 'May somebody (e.g. send me his number)')

P. $p d k$ (pozdro dla kumatych 'Greetings to the smart ones')

P. $s b$ (siebie 'myself' [ACC.])

P. $t b$ (tobie 'you' [DAT.])

\section{Conclusion}

A corpus-based study of English acronyms and alphabetisms used in contemporary Polish has revealed that English-sourced abbreviations are subject to substantial alterations at various levels of the recipient language system. Nativization and assimilation processes, in particular those that occur at the post-borrowing phase, facilitate the integration of the borrowed A\&As in the recipient language and alter the English faces of abbreviations to a degree at which they are no longer associated with their etymons or recognized as of English origin. English-sourced A\&As are creatively adapted by Polish users: borrowed abbreviations mesh with native morphemes to form expressions in the recipient language that are independent of any foreign etymons. Contact-induced A\&As have the potential to change formally and semantically in the recipient language, and also to reflect the socio-cultural connotations of the recipient speech community, as in the case of the augmentative forms that are carriers of social emotions. Moreover, language contact boosts the linguistic creativity of the recipient language users and intensifies the productivity of native abbreviation processes.

Language contact should be seen as a stimulus for language change and development. The linguistic history of Europe shows that intensive long-term language contact (e.g. Latin in medieval Europe) does not prevent the recipient languages from independent development and linguistic diversification, which indeed may be considered a lucky paradox in a situation of an intensive language contact.

\section{Dictionaries and corpora}

FD = The Free Dictionary. [http://www.thefreedictionary.com/].

LPD = Wells J.C. (ed.). 1995. Longman Pronunciation Dictionary. London.

MSSiMP = Miejski słownik slangu i mowy potocznej. [https://www.miejski.pl/]. 
NKJP = Przepiórkowski A., Bańko M., Górska R.L., Lewandowska-Tomaszczyk B. (eds.). 2012. Narodowy Korpus Języka Polskiego [= National Corpus of Polish]. Warszawa. [http://http://nkjp.pl/].

OLD = Oxford Learner's Dictionaries. [https://www.oxfordlearnersdictionaries.com/].

PWN = Słownik języka polskiego PWN. [https://sjp.pwn.pl/].

SSiSA = Kostyra M. 2006. Słownik skrótów i skrótowców angielskich. Kraków.

WSSiS = Müldner-Nieckowski P. 2007. Wielki słownik skrótów i skrótowców. Wrocław.

\section{References}

Dunn J. 2008. Face control, electronic soap and the four-storey cottage with a jacuzzi: Anglicisation, globalisation and the creation of linguistic difference. - Fisher R., Pułaczewska H. (eds.). Anglicisms in Europe: Linguistic diversity in a global context. Newcastle upon Tyne: 52-69.

Fisiak J. 1961. Zjawisko depluralizacji niektórych rzeczowników angielskich zapożyczonych przez język polski. - Język Polski 41.2: 138-139.

Jaworski S. 2014. Contact-induced changes in Polish morphology. - Koll-Stobbe A., Knospe S. (eds.). Language contact around the globe: Proceedings of the LCTG3 conference. Frankfurt am Main: 25-45.

Konieczna E. 2012. Lexical blending in Polish: A result of the internationalisation of Polish lexis. - Renner V., Maniez F., Arnaud P. (eds.). Cross-disciplinary perspectives on lexical blending. Berlin, Boston: 51-74.

Mańczak-Wohlfeld E. 1995. Tendencje rozwojowe współczesnych zapożyczeń angielskich w języku polskim. Kraków.

Przybylska R. 2008. Problemy pisowni i wymowy skrótowców z języka angielskiego. - LingVaria 2.6: 107-113.

Przybylska R. 2010. Jakiego rodzaju gramatycznego jest zombie i CD? Jeszcze raz o rodzaju gramatycznym rzeczowników zapożyczonych z języka angielskiego. - Język Polski 90.4-5: 246-255.

Przybylska R. 2012. Rodzaj gramatyczny skrótowców angielskich w polszczyźnie. - Pachowicz M., Choińska K. (eds.). Mundus verbi in honorem Sophiae Cygal-Krupa. Tarnów: 326-331.

Pulcini V. 2002. Italian. - Görlach M. (ed.). English in Europe. Oxford: 159-167.

Waszakowa K. 2001. Różnorodność i intensywność procesów przejmowania elementów obcych w słowotwórstwie współczesnej polszczyzny. - Poradnik Językowy 6: 2-14.

Witalisz A. 2015. English loan translations in Polish: Word-formation patterns, lexicalization, idiomaticity and institutionalization. Frankfurt am Main.

Witalisz A. 2016. Przewodnik po anglicyzmach w języku polskim. Kraków.

Witalisz A. 2018. Contact-induced right-headed interfixless $\mathrm{N}+\mathrm{N}$ compounds in Polish. A corpus-based study. - Studies in Polish Linguistics 13.1: 45-67. 